\title{
"Suffering" 1: Commodification of Music and the Effects of 1980 Military Coup On the Music Industry in Turkey
}

\author{
Ozan Eren \\ Ph.D. Student, Department of Sociology, Mimar Sinan Fine Arts University, İstanbul, Turkey \\ ozaneren84@hotmail.com
}

\section{Doi:10.5901/ajis.2015.v4n3p103}

\begin{abstract}
By using Adorno and Horkheimer's concept of 'culture industry' as a theoretical lens, this study aims to explore the rise of arabesque music and the dominance of the theme of "suffering" during the 1980s in Turkey. For this reason, using the concept of "culture industry", a content analysis of the lyrics of randomly selected 20 arabesque songs which give the names to the albums produced between 1981 and 1986 was conducted within the scope of proposed analysis. The empirical analysis in this paper will demonstrate that after the 1980 coup, music industry was confronted with difficulties such as state monopoly on radio and television broadcasting, conformity rather than consciousness, the effort to create citizenry who was uncritical and the commodification of music. During this period, while the country suffered from the disastrous effects of the 1980 coup on one side, it at the same time glorified a music form, which mostly consisted of themes of suffering, on the other side.
\end{abstract}

Keywords: The 1980 coup, culture industry, arabesque music, Turkey

\section{Introduction}

Starting from the 1960 coup, growing out of tensions, Turkey has experienced several types of coups throughout its history. The military interventions in Turkey had various negative effects on Turkish society in many fields. In order to internalize the effects of military coups, we need to examine the structural transformations of the political and social life after the implementation of the military interventions. Considering the reason that musical field plays a crucial role in our daily lives, the effects of military interventions on music industry need to be investigated and pursued in a transparent and comprehensive manner. In the light of what is said, standardization and commodification of music after the 1980 coup as important issues need to be addressed. For this reason, arabesque music conformed with socio - political circumstances in Turkey after the 1980 coup needs to be analyzed.

How the 1980 coup has affected the emergence of mass music industry in Turkey when considering arabesque music and the lyrics of songs produced after the 1980s and to what degree this emergence can be described in the light of "culture industry" defined by Adorno and Horkheimer is a vitally important issue to discuss, because Adorno and Horkheimer claim that "the whole world is made to pass through the filter of the culture industry, by being nothing other than style, it divulges style's secret: obedience to the social hierarchy." (Adorno \& Horkheimer, 2000: 7-11). The main purpose of this paper is to situate and analyze the proliferation of arabesque music in the context of the 1980 military coup. Using the concept of "culture industry", I will conduct a content analysis of the lyrics of randomly selected 20 arabesque songs which give the names to the albums produced between 1981 and 1986, and I will discuss the emergent themes in these songs with respect to "suffering" as the dominant theme. To begin with, in order to understand the proliferation of arabesque music during the 1980s, it is important to take a look at the sociopolitical and economic atmosphere of the 1980s.

\section{Brief Historical Background}

Before 1980, culture wasn't mit - induced and mass political advertising wasn't widespread in Turkey. "The 1983 elections in Turkey saw, for the first time, mass political advertising." (Özbek, 1997: 219). Due to the lack of exportation, there was economic distress and there was a lack of foreign exchange. Although television was introduced to the

${ }^{1}$ An arabesque song by Ferdi Tayfur from the 1980 s 
markets, there was one state - run channel. There were only a few discothéques. Arabesque music emerged at the end of 1960s was still being appreciated by slum house dwellers. "Since the end of the 1970s, arabesque as a musical genre had evolved, mutated, and proliferated as it became more popular and gained, through improved technology, a wider and more diversified reception." (Özbek, 1997: 220). It might be also alleged that, in this period, capitalist mode of production wasn't developed and mass production of art had not yet occurred. On the other hand, state - run Turkish Radio and Television Corporation (TRT) restricted many songs during the 1970s. "Especially from the mid - 1970s onwards, TRT has become a major arena for party politics. TRT's director - generals and other high positions have changed after every change of government. This has had disastrous effects on TRT's long - term planning." (Kejanlıoğlu, 2001: 123).

\section{Military Regime}

The military intervention in 1980, implemented for a sharp change and transition, had many negative effects on Turkish society in several fields. "Marking the beginning of the structural transformation of the political and social life in the country stretching to present day," (Elmas \& Kurban, 2010: 417) "the 1980 coup, proved to be far greater and repressive in scope and objectives than in 1960 or 1971." (Sayarı, 1992: 28). In other words, the 1980 coup might be considered as a dilemma of Turkish democracy. In a democratic country, government cannot be under military control. Besides, critical thinking and different voices cannot be suppressed in democracies. However, "1980 period was characterized by attacks on opposition groups and by a process of uniformization where even the most benign form of dissent was prohibited and suppressed." (Elmas \& Kurban, 2010: 417). The main reason behind the attacks on opposition groups and the process of uniformization was obvious:

The aim was to create a citizenry which was uncritical, non-interfering and ready to sacrifice their individuality in the name of the 'nation'. The media, especially the television, was the most important tool for realizing this aim and was used very effectively. (Elmas \& Kurban, 2010: 417, 418).

Although there are many visible and invisible reasons behind this coup, "political impotence" and "economic reasons" seem to be the dominant reasons. The intervention resulted in the Constitution of 1982 which has been widely criticized. There are two main reasons to criticize the Constitution of 1982. Firstly, the constitution was introduced during the military rule under the auspices of military authorities. Secondly, it contained many antidemocratic rules.

Regarding political impotence, political murders and inability to elect president of Turkish Republic after many voting rounds can be cited as main reasons behind the coup. In addition, as Doğu Ergil implies, "When corruption and inefficiency had reached an intolerable level, the bureaucratic-military complex stepped in again in 1980 and cleared the political scene of all existing actors." (Ergil, 2000: 56)

Regarding economy, increase in foreign trade deficit, foreign exchange crisis and unemployment rates seem to be the dominant reasons. As Çağlar Keyder has indicated, "in 1977 the average daily wage in Turkey was 11.14 dollars; this compared with 11.72 in Greece, 20.48 in France and 23.56 in Britain." (Keyder, 1987: 161) Turkey was facing serious economic problems.

Ergil writes that "in the years following the 1980 coup, legal and human rights violations reached extreme levels. Political parties were banned and their affiliates liquidated, and leading members of defunct parties were barred from the political and electoral process". (Ergil, 2000: 56). The 1980 coup also impacted on the social and cultural life negatively because of lack of freedom of expression. Many musicians were arrested because of their political stance. TRT banned many musicians such as Edip Akbayram and Zülfü Livaneli, representing left wing in music, whose political stance is reflected in their music. They were performing and/or composing songs without ignoring a critical attitude against injustices regarding sociopolitical atmosphere in the country. However, there was a state monopoly on radio and television broadcasting. Adorno and Horkheimer state that "under monopoly all mass culture is identical, and the lines of its artificial framework begin to show through." (Adorno \& Horkheimer, 2000: 3). When considering its effects on music industry and our daily lives, it might be alleged that, we, as listeners, were also restricted, because of forced unavailability of many songs and musicians in mass media. "Until the emergence of private television and radio channels in the 1990s, only the leading singers were allowed to perform on national holidays." (Özbek, 1997: 221). As a result, there has been an inevitable shift to standardized music. Thus, it might be asserted that censorship and standardization have flourished in an analogous way. 


\section{Three Phases of the 1980 Coup}

In addition to politics, the 1980 coup had also great impact on Turkish economy. Thus, Turgut Özal, assistant of Minister of State for Economic Affairs between September 1980 and 1983 and the president of Turkey between 1983 and 1989, had efforts on reshaping the economy. Sabri Sayarı notes the following:

Özal's efforts to reshape the economy during 1980 - 1988 took place in the context of three different phases of political change from authoritarian rule to democratic policies. From 1980 to 1983, economic policies were formulated under an authoritarian military government. After 1983, Turkey gradually moved from military rule to limited political liberalization (1983 - 1987), and then to greater political opening and redemocratization. (Sayarı, 1992: 29).

This transition towards political liberalization wasn't as easy and successful as it seemed, because the effects of the first and the second phases were extending the periods they emerged. Arabesque music proliferated during the second half of the 1980s, as it "became the most widespread music across the country, the earlier public awareness of poverty and subordination at the urban peripheries waned." (Özbek, 1997: 220). This period is characterized by limited political liberalization. In order to understand this proliferation from a theoretical framework, in the next section I will focus on the concepts of standardization and commodification.

\section{Standardization and Commodification of Music}

Many musicians standardized their music by similar themes and melodies in order to escape limited freedom or to conform with circumstances. This has also served for capitalist industrial production of music in Turkey. Adorno states the following:

The culture industry fuses the old and familiar into a new quality. In all its branches, products which are tailored for consumption by masses, and which to a great extent determine the nature of that consumption, are manufactured more or less according to plan. (Adorno, 1991: 85)

This is what we exactly experience by arabesque music produced in 1980s. Arabesque music was fusing the old and familiar into a new quality. Through the impression of mass media and political campaigns of Turgut Özal using arabesque music, it was becoming more popular and appreciated by millions of people by the day. "With the influence of mass media, arabesque also came to characterize the lifestyle, tastes, and sentiments of a newly rich group with provincial origins: new economic elites of finance, commerce, and trade." (Özbek, 1997: 220) This may also be explained by commodification of music with regard to Marx's definition of "commodification". "To Marx, the commodity form possesses the peculiar capacity of concealing its own essence and origin from the human beings who live with it and by it. The form is fetishized. It appears to be a thing endowed with boundless powers." (Lefebvre, 1968: 47) In this way, music is secondary important when it is produced, because it is commodified by its producer. Taylor clarifies this statement: "Explicitly or implicitly, writer after writer decries the commodification of music, music made expressly for the purpose of making money, not art..." (Taylor, 2007: 281).

\section{Arabesque Music as a Genre}

Before analyzing the emerging themes, defining arabesque music as a genre clearly is essential. Arabesque music as defined by Meral Özbek is "a new hybrid genre mixing Turkish classical and folk elements with those of the West and Egypt." (Özbek, 1997: 211). Since the 1970s, there have been many discussions about the reasons of the rise of arabesque music. "In the majority of these explanations, arabesque is seen as a threat in its so-called impurity, fatalistic outlook, and degeneration." (Özbek, 1997: 211). However, "after 1980, arabesque gained a negative political connotation as well, owing to its affiliation with the neoliberal practices of the Motherland Party". (Özbek, 1997: 219). Thus, it might be asserted that arabesque music has conformed with socio - political circumstances in Turkey after the 1980 coup. This was serving for the purposes of Özal's regime. Özalist political campaigns using arabesque music was also facilitating to make arabesque music more popular, as mentioned earlier. Therefore, it would be accurate to claim that there was a mutual relation between Özal's regime and arabesque music. In this mutual relation, arabesque musicians and Özal were both offering advantages. These illustrate that arabesque music was taking place in culture industry, "the power of the culture industry's ideology is such that conformity has replaced consciousness." (Adorno, 1991: 90). At this point, it might be helpful to clarify policies of Özal and Motherland Party: 
Özal, in fact, was genuinely fond of the music and employed it to support his themes that all Turks were "lovers" and that he respected and welcomed all of the four main political ideologies (extreme right, Islamist, center right, and social democrat) into Motherland's fold (Özbek, 1997: 220).

It might be asserted that the more widespread arabesque music was becoming, the more unconscious listeners were becoming. This was also serving to create a citizenry which was uncritical and integrated to the system of culture industry. In addition, appreciation of arabesque music by Özal and strong ties between mass music industry and Motherland Party might connote the following fact:

Talented performers belong to the industry long before it displays them; otherwise they would not be so eager to fit in. The attitude of the public, which ostensibly and actually favors the system of the culture industry, is a part of the system and not an excuse. (Adorno \& Horkheimer, 2000: 4)

\section{Data and Methods}

Arabesque music "which began to be used as a metaphor for Özal's regime" (Özbek, 1997) needs to be analyzed in the light of culture industry. For this purpose, a content analysis of the lyrics of randomly selected 20 arabesque songs which give the names to the albums produced between 1981 and 1986, and analysis of the emergent themes in these songs with respect to "suffering" as the dominant theme will provide us a comprehensive analysis of the 1980 coup by considering its effects on music. As mentioned before, although three different phases of political change from authoritarian rule to democratic policies took place as the impact of 1980 coup, the first two phases were dominant phases in 1980s which lasted seven years. Therefore, because 1987 might be considered as a smooth transition to the last phase, the year of 1986 was taken as the last year of content analysis. After deciding on the time period, the other crucial decision is to choose the arabesque musicians, because there were many arabesque musicians in this period. I pick the most popular musicians, namely Ferdi Tayfur, Ibrahim Tatlıses, Orhan Gencebay, Müslüm Gürses, Kibariye and Bergen. Among all, Kibariye - arabesque and pop music singer - and Bergen - arabesque and fantasy music singer were less popular and the effects of their music were relatively less lasting. For this reason, two songs from Kibariye and Bergen were chosen while four songs from the others were chosen. After the data collection from the internet, I gathered all of the songs of the musicians giving their names to the albums and I randomly selected songs from this database assuming that at least three songs will be chosen from each year regardless of the name of the artist. The numbers of chosen songs are illustrated in Table 1.

Table 1. Songs Per Year

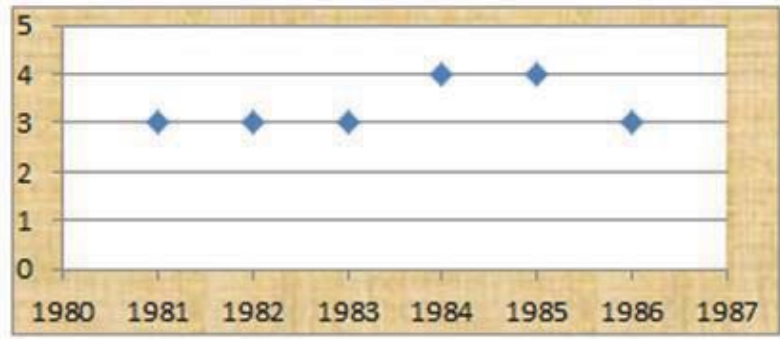

After collecting the data, twenty songs were categorized according to emerging themes. Emerging themes from these songs were "frustration at love", "separation from beloved", "vain of mundane life", "suffering from death of beloved", "suffering from a life of deprivation", "suffering from exhaustion, anxiety and solitude", "suffering from unrequited love", "joy of love", "joy of life" and "individual fatalism". Emerging themes are given in Table 2. 
Table 2. Emerging Themes

\begin{tabular}{|c|c|c|c|c|}
\hline Name of the artist & $\begin{array}{l}\text { Album } \\
\text { Release }\end{array}$ & Song \& Album Name & Theme & $\begin{array}{l}\text { The Number of Total Albums } \\
\text { as of } 1986\end{array}$ \\
\hline \multirow{4}{*}{ Ferdi Tayfur } & 1981 & İnsan Sevince & Frustration at love - unrequited love - telling by talking to God & \multirow{4}{*}{11 albums } \\
\hline & 1983 & Sen De Mi Leyla & Frustration at love - unrequited love & \\
\hline & 1984 & Yaktı Beni & Frustration at love - unrequited love - telling by talking to God & \\
\hline & 1985 & Kurtuldum & Separation from beloved, then, joy of love with God & \\
\hline \multirow{4}{*}{ İbrahim Tatlıses } & 1981 & Gülmemiz Gerek & Joy of life - hope from future & \multirow{4}{*}{19 albums } \\
\hline & 1982 & $\begin{array}{l}\text { Yaşamak Bu } \\
\text { Değil }\end{array}$ & Separation from beloved - regretting the old mistakes & \\
\hline & 1983 & Yalan & Vain of mundane life, love of God & \\
\hline & 1984 & Benim Hayatım & Suffering from exhaustion, anxiety and solitude & \\
\hline \multirow{4}{*}{ Orhan Gencebay } & 1983 & Leyla ile Mecnun & Suffering from death of beloved & \multirow{4}{*}{5 albums } \\
\hline & 1984 & Dil Yarası & Frustration at love & \\
\hline & 1985 & Beni Biraz Anlasaydın & Separation from beloved & \\
\hline & 1986 & Cennet Gözlüm & Suffering from love - unrequited love & \\
\hline \multirow{4}{*}{ Müslüm Gürses } & 1981 & Esrarlı Gözler & Joy of love & \multirow{4}{*}{17 albums } \\
\hline & 1984 & Güldür Yüzümü & Suffering from unrequited love & \\
\hline & 1985 & Sevda Yolu & Separation from beloved - being left & \\
\hline & 1986 & Yıkıla Yıkıla & Suffering from a life of deprivation & \\
\hline \multirow[b]{2}{*}{ Kibariye } & 1982 & Aşkın Adresi & Frustration at love & \multirow[b]{2}{*}{4 albums } \\
\hline & 1985 & Hayat Merdiveni & Suffering from a life of deprivation & \\
\hline \multirow{2}{*}{ Bergen } & 1982 & Şikâyetim Var & Individual fatalism & \multirow{2}{*}{6 albums } \\
\hline & 1986 & Acıların Kadını & Suffering from a life of deprivation & \\
\hline
\end{tabular}

Music has an important place in our daily lives and it directly or indirectly affects our lifestyles. Therefore, the lyrics of the songs as shaping our daily lives deserve a careful analysis. When analyzing the emerging themes of the randomly chosen 20 arabesque songs, it is realized that only two songs have positive connotations which emphasize themes such as "joy of life - hope from future" and "joy of love". However, the other songs have negative connotations. This means that $90 \%$ of the songs have negative meanings. Another important point to note is that although the country suffered from the disastrous effects of the 1980 coup, the lyrics of the arabesque songs don't contain any criticism of political atmosphere of the 1980s or posit a resistance against the system. The lyrics are so simple that any citizen suffering from goings, suffering from unrequited love or separated from beloved can express his/her feelings the same way. On the other hand, the number of the arabesque albums issued between 1981 and 1986 are noteworthy. ${ }^{2}$ Even Kibariye who had the least albums in this period could release four albums. Extremism in the number of arabesque albums illustrates us that what the importance for arabesque musicians is not the quality, but the quantity as the culture industry imposes.

If we accept music as the most effective channel of communication with the public body, to be or not to be an arabesque musician in this period could be better discussed in the light of culture industry by observing some of the leftist musicians such as Edip Akbayram who positioned his political stance in a coherent way over the years. According to Adorno and Horkheimer, "the culture industry refutes the objection made against it just as well as that against the world which it impartially duplicates. The only choice is either to join or to be left behind." (Adorno \& Horkheimer, 2000: 18). 1980s were difficult years for Edip Akbayram. He was under pressure to change his music to arabesque style. However, he always refused to sing in arabesque. This illustrates that Akbayram was resisting the influence of culture industry. As a result of his resistance, from 1980 to 1984, Akbayram was jobless. This resistance might be also discussed in the light of Adorno and Horkheimer as they write, "man as a member of a species has been made a reality by the culture industry. Now any person signifies only those attributes by which he can replace everybody else; he is interchangeable, a copy." (Adorno \& Horkheimer, 2000: 16). While arabesque musicians could be able to release their albums once or twice a year, there were jobless musicians such as Edip Akbayram who didn't commodify his music by ignoring his political stance and did not become a part of "culture industry" or a cog in the culture machine.

2 In order to learn the exact number of albums released between 1981 and 1986, I sent an Information Application Form to the Ministry of Culture and Tourism in Turkey. However, I was informed that only the albums with the registration number registered by the Ministry can be counted. In addition to this information, I was informed that it is not possible to inform me about the exact number of albums released between 1981 and 1986. I was only informed about the number of total albums released by mentioned arabesque musicians as of 1986. Therefore, I tried to obtain the data from the official websites of the musicians and some internet resources regarding the number of albums released in six - year period. On the other hand, as illustrated in Table 2, according to the data obtained from the Ministry of Culture and Tourism, the number of total albums as of 1986 is also an evidence of extremism. 


\section{Conclusion}

To sum up, after the analysis of arabesque music which became a more commercial genre in 1980s and the lyrics of songs produced between 1981 and 1986 by prominent arabesque musicians, it might be said that arabesque music took place in culture industry by conforming with sociopolitical circumstances in Turkey after the 1980 coup. After the 1980 coup, music industry was confronted with difficulties such as state monopoly on radio and television broadcasting, conformity rather than consciousness, creating a citizenry which was uncritical and commodification of music in Turkey. If the idea that an artist should be a thinker, creative and masterful in expressing his/her ideas is ignored in a country, culture industry dominates over musicians. This is exactly what we experience by the 1980 coup and its implications.

\section{Acknowledgments}

The preliminary version of this essay was presented at the $3^{\text {rd }}$ Global Conference called "Making Sense of Suffering", held at Salzburg in Austria, in 2012. The author wishes to express his profound thanks to his teacher Işıl Çelimli for her invaluable contributions in the drafting of this essay.

\section{References}

Adorno, T. W. (1991). Culture Industry Reconsidered. In The Culture Industry: Selected Essays on Mass Culture, Ed. by J. M. Bernstein, London: Routledge.

Adorno, T. \& Horkheimer, M. (2000). The Culture Industry: Enlightenment as Mass Deception. In Juliet B. Schor and Douglas B. Holt, (Eds.), The Consumer Society Reader (pp. 3-19). New York: The New Press.

Elmas, E. \& Kurban, D. (2010). Media policies and regulatory practices in a selected set of European countries, the EU and the Council of Europe: The case of Turkey. European Commision Report. Retrieved from http://www.mediadem.eliamep.gr/wpcontent/uploads/2010/05/BIR.pdf

Ergil, D. (2000). Indentity Crises and Political Instability in Turkey. Journal of International Affairs, Vol. 54 (1), $43-62$.

Kejanlıoglu, D. B. (2001). Media in Turkey Since 1970. In Lovatt, D. (Eds.), Turkey Since 1970 (pp. 111-135). London: Palgrave.

Keyder, Ç. (1987). State and Class in Turkey: A Study in Capitalist Development. Verso, New York.

Lefebvre, H. (1968). The Sociology of Marx. New York: Pantheon Books

Özbek, M. (1997). Arabesk Culture: A Case of Modernization and Popular Identity. In Bozdoğan, S. \& Kasaba, R. (Eds.), Rethinking Modernity and National Identity in Turkey (pp. 211-232). University of Washington Press.

Sayarı, S. (1992). Politics and Economic Policy-Making in Turkey, 1980-1988. In Nas, T. \& Odekon, M. (Eds.), Economics and Politics of Turkish Liberalization (pp. 26-43). Bethlehem: Lehigh University Press.

Taylor, T. D. (2007). The Commodification of Music at the Dawn of the Era of 'Mechanical Music'. Ethnomusicology, 51(2), 281 - 305 